\title{
The role of the large intestine in post-ruminal digestion of feeds as measured by the mobile-bag method in cattle
}

\author{
BY AILA VANHATALO' AND ELISE KETOJA ${ }^{2}$ \\ ${ }^{1}$ Institute of Animal Production and ${ }^{2}$ Data and Information Services, Agricultural Research Centre \\ of Finland, FIN-31600 Jokioinen, Finland
}

(Received 4 January 1994 - Revised 7 June 1994-Accepted 17 August 1994)

\begin{abstract}
To study the importance of site of recovery and other factors related to mobile-bag (MB) digestion values, two consecutive experiments in which diets were applied in a $3 \times 3$ Latin square design, were carried out with cannulated growing heifers. In Expt 1, several types of experimental feed were exposed to intestinal digestion in mobile bags made of two cloth types and filled with intact or rumenundegradable (RUD) feed material to be recovered either from the ileum (IB) or faeces (FB). In Expt 2, mean retention time (MRT) of Yb-labelled digesta particles within the intestine and in vivo digestibility of diets were measured. With vegetable concentrates, FB resulted generally in slight overestimation of small-intestinal dry matter and $\mathbf{N}$ digestion, while with meat-and-bone meal no difference between FB and IB was found. The respective $N$ digestibility of RUD late-cut silage was clearly underestimated as measured from FB. The disappearance of neutral-detergent fibre (NDF) of all feeds under test was higher from FB than from IB. It was not possible to isolate the influence of the large intestine on the MB values by changing bag cloth type. Irrespective of the longer retention time of bags and longer MRT of Yb in the intestine on a low as compared with a high level of feeding, only NDF disappearance of feeds increased due to lower feeding level. Altering the diet type to increase largeintestinal fermentation, as indicated in vivo, usually had no effect on the MB values. It is concluded that the site of collection of bags does not practically affect small-intestinal digestion values of feed $N$, unless the feed is rich in fibre.
\end{abstract}

Post-ruminal digestion: Large intestine: Mobile-bag method

In the modern feed-protein evaluation systems for ruminants, information about the intestinal digestibility of bypass protein is required. Little information is available and more studies on intestinal digestibility of feed protein are needed. However, assessment of true $\mathbf{N}$ digestibility in ruminants is difficult due to the close association of rumen-undegradable feed with microbial biomass and endogenous secretions. An approach to overcome this problem is the mobile-bag method, originally introduced to measure the protein digestibility of feedstuffs in pigs (Sauer et al. 1983). It has also been applied to study post-ruminal digestion of feedstuffs in ruminants (Voigt \& Piatkowski, 1983; Hvelplund, 1985; Kirkpatrick \& Kennelly, 1985; Rae \& Smithard, 1985; Rooke, 1985). In this method a small amount of experimental feed material is enclosed in a nylon bag and sent through the intestine via a duodenal cannula to be collected later from an ileal cannula or mostly, for practical reasons, from faeces. Mobile-bag measurements have been made from intact feeds or from their rumen-undegradable residues after variable periods of rumen-incubation (e.g. Hvelplund, 1985; Voigt et al. 1985; De Boer et al. 1987; Varvikko \& Vanhatalo, 1990; Hvelplund et al. 1992). Hvelplund et al. (1992) have, however, suggested that intestinal digestibility of $\mathrm{N}$ could be calculated based on information about intestinal digestibility of intact feed only. 
Digestion values obtained are often considered to represent true rather than apparent digestibility of undegraded dietary protein (Rae \& Smithard, 1985; De Boer et al. 1987; Hvelplund \& Madsen, 1990; Van Straalen \& Tamminga, 1990). More clarification, however, is needed to apportion the intestinal digestion of different feeds between the small and large intestines (Varvikko \& Vanhatalo, 1990). Ulyatt et al. (1975) emphasized an increasing proportion of large-intestinal digestion in cases where apparent digestibility of the diet was decreased. It has also been stated that the large intestine of ruminants can account for as much as $27 \%$ of cellulose and $40 \%$ of hemicellulose digested daily (Hoover, 1978). Hvelplund (1985), using the mobile-bag method, found that small-intestinal digestibilities of soya bean and rapeseed meal were overestimated when bags were recovered from faeces. He pointed out the need to study the importance of the digestion process in the large intestine, and to determine whether it is necessary to correct for it. Few other comparisons between ileum and faeces as sites of recovery of bags have been published (Voigt et al. 1985; Hvelplund, 1986; Jarosz et al. 1991). In any of these, however, the effect of diet per se has not been included as a possible factor affecting the intestinal digestion values.

Moreover, it has been noted that the bag cloth may significantly affect disappearance values obtained by the mobile-bag method (Varvikko \& Vanhatalo, 1990; Todorov \& Girginov, 1991). In the study by Varvikko \& Vanhatalo (1990), free surface area (small (S) $v$. large (L)) of cloth was even more important than pore size as a determinant of disappearance values. Previously, it has been noted that the microbial population inside the bag differs and is smaller from that of the surrounding digesta in the rumen. Meyer \& Mackie (1986) found that the counts of total culturable bacteria in bags with a pore size of $10 \mu \mathrm{m}$ were less than $30 \%$ and with a pore size of $53 \mu \mathrm{m}$ less than $82 \%$ of the ruminal counts. Huhtanen \& Khalili (1992) found also that particle-associated carboxymethylcellulase $(E C$ 3 2.2.1.4) and xylanase $(E C$ 3.2.1.8) activities were much lower in feed particles incubated in the rumen in nylon bags compared with those in the rumen particulate material. Hence, a question arises whether the contribution of microbes within the large intestine to the mobile-bag digestion values could be isolated by using appropriate cloth material.

The present study was designed to assess the importance of site of recovery on mobilebag digestion values of several types of ruminant feed. To ascertain whether the effect of recovery site was dependent on the pre-treatment of samples (intact $v$. rumen-undegradable feeds), type of cloth (S v. L) or diet (feeding level, diet type), these factors were included in the study. Two consecutive experiments, in which diets were arranged according to a $3 \times 3$ Latin square, were carried out. In Expt 1 the intestinal digestibility of either intact or rumen-incubated experimental feeds within mobile bags made of two different cloth types and recovered either from ileum or faeces were measured. In Expt 2 the in vivo digestibility and mean retention time of $\mathrm{Yb}$-labelled digesta particles within the intestine were assessed.

\section{MATERIALS AND METHODS}

Animals and their feeding

Three growing heifers (initial live weight (W) $270 \mathrm{~kg}$ ) of the Finnish Ayrshire breed were used in the experiments. They were each fitted with a rumen cannula and simple $T$-piece cannulas in the proximal duodenum and in the distal ileum. In both experiments the animals were fed on diets A40, A80 and B80, which were applied in a $3 \times 3$ Latin square design. Diets A40 and A80 consisted of grass silage and bariey (70:30 on a dry matter $(\mathrm{DM})$ basis) and they were given at two levels of DM intake (40 and $80 \mathrm{~g} \mathrm{DM} / \mathrm{kg} \mathrm{W}^{0.75}$ 
Table 1. Ingredients and chemical composition of experimental diets

\begin{tabular}{lccc}
\multicolumn{1}{c}{ Diet... } & A40 & A80 & B80 \\
\hline Ingredients (g dry matter $/ \mathrm{d}$ ) & & & \\
$\quad$ Grass silage & 2122 & 4032 & 1171 \\
$\quad$ Barley & 891 & 1720 & 1716 \\
$\quad$ Dried and pelleted grass & & & 1969 \\
Sucrose* & 117 & 117 & 117 \\
$\quad$ Minerals & & & \\
Chemical composition (g/kg dry matter) & 913 & 928 & 923 \\
$\quad$ Organic matter & $22 \cdot 2$ & $22 \cdot 6$ & $21 \cdot 1$ \\
$\quad$ Nitrogen & 444 & 452 & 358 \\
$\quad$ Neutral-detergent fibre & & \\
\hline
\end{tabular}

* Sucrose was given as a continuous intrarumen infusion.

respectively). Diet $\mathrm{B} 80$ was fed at the same level of DM intake as diet A80, but consisted of grass silage, dried and pelleted grass, barley and sucrose (20:35:30:15 on a DM basis). When equated to the maintenance level of energy requirements of heifers (Agricultural Research Council, 1980), the experimental diets provided 1, 1.9 and 2.1 times maintenance respectively. Sucrose was infused continuously into the rumen in an aqueous solution $(0.44 \mathrm{~g} / \mathrm{ml})$ at a rate of $83 \mathrm{ml} / \mathrm{h}$ using a peristaltic pump. Dried and pelleted grass (Agricultural Research Council, 1984) as well as a sucrose infusion (Huhtanen \& Khalili, 1991) were given in order to shift digestion from the forestomachs towards the hindgut. Increased hindgut fermentation was encouraged to study whether the degree of hindgut fermentation had any effect on digestion values obtained by the mobile-bag method. A commercial mineral mixture $(120 \mathrm{~g} / \mathrm{d})$ was given to the animals and water was freely available. The animals were fed in two equal meals at $12 \mathrm{~h}$ intervals. The experimental period of $28 \mathrm{~d}$ included a $10 \mathrm{~d}$ adaptation period. At the beginning of each period the change in the rumen environment of each animal was accelerated by transferring 15 litres of rumen contents from the animal previously fed on that particular diet. Ingredients and average chemical composition of the diets in the experiments are presented in Table 1.

\section{Experimental feeds}

Experimental feeds used in the mobile-bag study were early-cut grass silage (ECS), late-cut grass silage (LCS), untreated rapeseed meal (RSM), heat-moisture treated (Öpex ${ }^{(3)}$ rapeseed meal (TRSM), soya-bean meal (SBM) and meat-and-bone meal (MBM). Grass silages were made of cocksfoot-timothy (Dactylis glomerata-Phleum pratense) sward. Ensiling of grass silages has been described previously (Aronen et al. 1992). Rapeseed meals (Brassica campestris) originated from a yellow-seeded 00-variety. Grass silages were freeze-dried and all feeds were milled to pass a $2 \mathrm{~mm}$ screen. Feed residues resistant to rumen degradation were prepared before experiment by incubating the experimental feeds in the rumens of four cannulated cattle for $12 \mathrm{~h}$. The nylon bag technique was used in rumen incubations as described by Vanhatalo et al. (1992).

\section{Mobile-bag technique}

In Expt 1, intact feeds and their rumen-undegradable (RUD) residues were weighed into mobile bags made of polyester with free surface area (pore area in percentage of total surface area of the cloth): pore size $(\mu \mathrm{m})$ ratios of $2: 10(\mathrm{~S})$ and 33:41 (L). Except for grass 
silage, approximately $1.1 \mathrm{~g}$ experimental feed was weighed into each bag. Only $0.8 \mathrm{~g}$ grass silage was weighed due to its bulkiness. Details of the preparation of bags have been given previously (Varvikko \& Vanhatalo, 1990). The S and L bags filled with intact or RUD feeds were introduced into the duodenum of animals in random order within each experimental feed. All bags were exposed to intestinal digestion on all experimental diets. On average twenty bags per animal per day were inserted, a maximum of four to five bags at one time.

Three of the six bags within every combination of pre-treatment $\times$ feed $\times$ cloth were extracted from the ileum (IB) by means of a shaped wire attached to the cap of the ileum cannula, and three bags were collected from the faeces (FB). The ileum cannulas and the faeces were checked every $2 \mathrm{~h}$, except for the $8 \mathrm{~h}$ interval during the night, and the retention time of bags in the intestine was recorded. After recovery the bags were machine-washed in a domestic washing machine $\left(40^{\circ}, 50 \mathrm{~min}\right)$, dried in a forced-draft oven $\left(60^{\circ}, 24 \mathrm{~h}\right)$ and weighed. The three bags per treatment combination were pooled to form one sample to be analysed chemically. In the event that collection at the ileum was not successful, however, the bag was collected from faeces and the residue was included in the sample for the corresponding FB measurement. Thus, three measurements per treatment combination were obtained for each response variable during the entire experiment.

Intact feed and RUD samples were analysed for DM, Kjeldahl-N, neutral-detergent fibre (NDF) and acid-detergent fibre (ADF) as described by Robertson \& Van Soest (1981). They were also analysed for soluble DM and $\mathrm{N}$ as proposed by Weisbjerg et al. (1990). After the exposure to intestinal digestion the samples were analysed for DM, Kjeldahl-N and NDF.

\section{In vivo digestion of diets}

To determine the rumen and total digestibilities of the diets, $3 \mathrm{~d}$ duodenal spot-sampling and $5 \mathrm{~d}$ faecal grab sampling in Expt 2 were carried out. The details of the procedures and marker techniques employed were described by Vanhatalo et al. (1992).

Mean retention time (MRT) of digesta was estimated by administering $30 \mathrm{~g}$ Yb-labelled digesta particles via the duodenal cannula on day 22 before the morning feed. Duodenal digesta for this purpose were collected from each animal on three consecutive days, filtered through a cheese-cloth and washed with tap water. Particles were labelled with $\mathrm{Yb}$ as described by Varga \& Prigge (1982) except that Yb-acetate instead of Yb-chloride was used. All the faeces excreted during the following $48 \mathrm{~h}$ were collected individually, weighed, mixed thoroughly and sampled. $\mathrm{Yb}$ concentration of the samples was determined as described by Huhtanen \& Kukkonen (1995). The MRT of Yb-labelled digesta particles within the intestine was calculated according to Blaxter et al. (1956).

\section{Statistical methods}

As there were many factors in Expt 1, and the difference in all response variables between intact and RUD feed materials was generally obvious, data for intact feeds and for RUD feed materials were analysed separately. The analysis of variance adopted was that for a split-split plot design. Animal-period combinations formed the main plots and diets were assigned as for a $3 \times 3$ Latin square. Feeds were assigned to sub-plot and cloth type $\times$ recovery combinations to sub-sub-plots. The model on which the analyses were thus based was the following mixed model:

$$
\begin{aligned}
& \mathrm{y}_{\mathrm{ijklmn}}=\mu+\mathrm{A}_{\mathrm{i}}+\mathrm{P}_{\mathrm{j}}+\mathrm{D}_{\mathrm{k}}+\mathrm{e}_{\mathrm{ijk}}+\mathrm{F}_{\mathrm{l}}+\mathrm{DF}_{\mathrm{k} \mathrm{l}}+\mathrm{f}_{\mathrm{j} \mathrm{jkl}}+\mathrm{R}_{\mathrm{m}}+\mathrm{C}_{\mathrm{n}}+\mathrm{RC}_{\mathrm{mn}}+\mathrm{DR}_{\mathrm{km}} \\
& +\mathrm{DC}_{\mathrm{kn}}+\mathrm{DRC}_{\mathrm{kmn}}+\mathrm{FR}_{\mathrm{lm}}+\mathrm{FC}_{\mathrm{ln}}+\mathrm{FRC}_{\mathrm{lmn}}+\mathrm{DFR}_{\mathrm{klm}}+\mathrm{DFC}_{\mathrm{k} l n}+\mathrm{DFRC}_{\mathrm{k} l m n}+\mathrm{g}_{\mathrm{ijklmn}} \text {, }
\end{aligned}
$$

where $\mu$ is the overall mean, $A$ and $P$ are the random effects of animal and period, $D, F$, $R$, and $C$ are the fixed effects of diet, feed, site of recovery and cloth type and $e_{i j k}, f_{i j k l}$ and 
$\mathrm{g}_{\mathrm{ijklmn}}$ are the random error terms for animal, bag group and bag respectively. Further, two-, three- and four-factor interactions of fixed effects were included in the model. The random variables, $A_{i}, P_{j}, e_{i j k}, f_{i j k l}$ and $g_{i j k l m}$ are all assumed independent and normally distributed with zero means and variances ${\sigma_{\mathrm{A}}}^{2},{\sigma_{\mathrm{P}}}^{2},{\sigma_{\mathrm{e}}}^{2},{\sigma_{\mathrm{f}}}^{2}$ and ${\sigma_{\mathrm{g}}}^{2}$ respectively. The statistical analyses concerning in vivo measurements of diets were based on a Latin square model, which included animal, period and diet effects only. All models were fitted by using the residual maximum likelihood (REML) estimation method.

The appropriatenesses of the models were studied by residual analyses (Neter et al. 1990). If the assumptions of the model were met by data, the distribution of the residuals should be approximately normal. The residuals were checked for normality using box plot (Tukey, 1977). Furthermore, the residuals were plotted against the fitted values. Such a plot should have the appearance of a random scatter of points if the assumptions of the model are adequate. Comparisons between means were made by using $t$ type confidence intervals. The analyses were performed by means of the SAS ${ }^{\circledR}$ system. The MIXED procedure (SAS, 1992) and UNIVARIATE and PLOT procedures (SAS, 1990) were used. The MIXED procedure fits mixed models to both balanced and unbalanced data.

\section{RESULTS}

Expt 1

Since with one particular animal the collection of the bags from the ileum was not always successful, many ileal bags were lost. For this reason, twenty-one ileal measurements with intact feeds and twenty-six with RUD feeds were lost respectively. In addition, three observations on bags filled with RUD RSM were lost due to an error that occurred in the preparation of samples. In any treatment combination, however, at least two measurements were successfully obtained. If focused across the feeds, at least seven from nine possible ileal measurements per feed were always obtained.

Chemical composition of test materials and losses of DM and $\mathrm{N}$ due to washing of intact and RUD feeds are given in Table 2. With the exception of SBM, pre-incubation in the rumen for $12 \mathrm{~h}$ decreased $\mathrm{N}$ and increased fibre concentration $(\mathrm{g} / \mathrm{kg} \mathrm{DM})$ of feeds. Means over diets for disappearance from bags of DM, N and NDF of intact and RUD feeds exposed to experimental treatments are given in Table 3. Any significant diet effects and other results from statistical analyses are given later in the text and Table 4 . Interactions between three or four factors are not reported as they were not statistically significant $(P$ $>0.09$ ). Furthermore, to ascertain that all important effects would be found, data for each of the feeds were analysed separately. Results from these analyses are reported if there was any additional information compared with the previous analyses. The checking of the models by residual analyses did not indicate any gross departures from the assumptions underlying the models. Generally, disappearance of feed nutrients from mobile bags was clearly higher for intact than for RUD feeds. Means for both of these feeds are presented separately, but results of analysis of variance for RUD feeds are stated in the text only if they were different from intact feeds.

\section{Dry matter disappearance from mobile bags}

The effect of site of recovery on DM disappearance from mobile bags within the intestine was dependent on feed $\left(F_{5,87}=9.36, P<0.001\right.$ for site of recovery $\times$ feed interaction). Except for MBM, DM disappearance was higher for feeds in FB than in IB (Table 4). For MBM the $95 \%$ confidence interval (CI) for the difference between the sites of recovery included zero (Table 4), which implies that the difference was not statistically significant at 
Table 2. Chemical composition of test materials and particle loss due to washing from bags (small $(S)$ and large $(L)$ free surface area of cloth) of intact $(I)$ and rumen-undegradable $(R U D)$ experimental feeds before intestinal exposure in cattle*

\begin{tabular}{|c|c|c|c|c|c|c|c|c|c|c|c|c|}
\hline \multirow[t]{2}{*}{ Feed. } & \multicolumn{2}{|c|}{ ECS } & \multicolumn{2}{|c|}{ LCS } & \multicolumn{2}{|c|}{ RSM } & \multicolumn{2}{|c|}{ TRSM } & \multicolumn{2}{|c|}{ SBM } & \multicolumn{2}{|c|}{ MBM } \\
\hline & I & RUD & I & RUD & $\mathbf{I}$ & RUD & I & RUD & I & RUD & I & RUD \\
\hline $\begin{array}{l}\text { Dry matter }(\mathrm{g} / \mathrm{kg}) \\
\mathrm{g} / \mathrm{kg} \text { dry matter }\end{array}$ & 912 & 953 & 910 & 955 & 937 & 925 & 937 & 925 & 937 & 932 & 963 & 959 \\
\hline Nitrogen & 28 & 9 & 26 & 8 & 60 & 46 & 60 & 56 & 80 & 110 & 79 & 56 \\
\hline $\begin{array}{l}\text { Neutral-detergent } \\
\text { fibre (NDF) }\end{array}$ & 492 & 859 & 542 & 874 & 255 & 543 & 263 & 469 & 130 & 220 & & \\
\hline Acid-detergent fibre & 276 & 483 & 304 & 490 & 178 & 433 & 183 & 384 & 90 & 144 & & \\
\hline Soluble dry matter & 367 & 10 & 313 & 15 & 188 & -9 & 150 & -7 & 292 & 0 & 67 & 3 \\
\hline \multicolumn{13}{|l|}{$\mathrm{g} / \mathrm{kg}$ total nitrogen } \\
\hline $\begin{array}{l}\text { Fibre-bound N } \\
\text { (NDF-N) }\end{array}$ & 89 & 352 & 100 & 409 & 96 & 322 & 104 & 213 & 29 & 52 & & \\
\hline Soluble $\mathrm{N}$ & 704 & 278 & 669 & 224 & 134 & 61 & 107 & 71 & 87 & 12 & 180 & 26 \\
\hline \multicolumn{13}{|l|}{$\begin{array}{l}\text { Loss due to washing } \\
(\mathrm{g} / \mathrm{kg})\end{array}$} \\
\hline \multicolumn{13}{|l|}{ Dry matter } \\
\hline S bags & 227 & 32 & 182 & 40 & 256 & 72 & 233 & 72 & 319 & 67 & 157 & 67 \\
\hline$L$ bags & 414 & 52 & 344 & 55 & 285 & 108 & 263 & 119 & 375 & 106 & 201 & 141 \\
\hline \multicolumn{13}{|l|}{ Nitrogen } \\
\hline$S$ bags & 401 & 72 & 354 & 46 & 197 & 72 & 148 & 100 & 107 & 66 & 287 & 100 \\
\hline L bags & 705 & 112 & 637 & 32 & 226 & 129 & 196 & 144 & 192 & 85 & 362 & 134 \\
\hline
\end{tabular}

ECS, early-cut silage; LCS, late-cut silage; RSM, rapeseed meal; TRSM, heat-moisture treated rapeseed meal; SBM, soya-bean meal; MBM, meat-and-bone meal.

* For details of procedures, see pp. $492-494$.

the $5 \%$ level. As regards practical significance of the difference, the CI states that a true difference between the sites of recovery might at maximum be $16 \mathrm{~g} / \mathrm{kg}$ in favour of faeces or $22 \mathrm{~g} / \mathrm{kg}$ in favour of the ileum. However, the difference of this magnitude or even double this magnitude, be it for FB or IB, was considered of no practical importance. With the exception of LCS, similar differences, although not so obvious for rapeseed meals, were found with RUD feeds.

It was not possible to isolate the influence of the large intestine on digestion values by manipulating cloth type $\left(F_{1,87}=1.08, P=0.30\right.$ for site of recovery $\times$ cloth type interaction $)$. However, clearly lower disappearance of feed DM from $\mathrm{S}$ bags compared with $\mathrm{L}$ bags (582 v. $640 \mathrm{~g} / \mathrm{kg}$ ) was found $(95 \%$ CI 50,65 for $\mathrm{L}-\mathrm{S}$ difference).

The effect of site of recovery on DM digestion values was not dependent on diet $\left(F_{2,87}\right.$ $=0.46, P=0.63$ for site of recovery $\times$ diet interaction), although the diet tended to have some influence $\left(F_{2,2}=11 \cdot 84, P=0.08\right)$. This was due to a difference of $30 \mathrm{~g} / \mathrm{kg}(90 \% \mathrm{CI}$ $10,48)$, which was found between the means $(630 v .601 \mathrm{~g} / \mathrm{kg})$ of diets A40 and A80. With RUD feeds the corresponding difference was negligible, only $14 \mathrm{~g} / \mathrm{kg}(90 \% \mathrm{CI}-9,37)$.

Nitrogen disappearance from mobile bags

The effect of site of recovery on feed $\mathrm{N}$ disappearance from bags was also associated with feed type $\left(F_{5,87}=3.14, P=0.01\right.$ for site of recovery $\times$ feed interaction $)$. The $\mathrm{N}$ disappearance from both rapeseed meals was higher, but that of other feeds only slightly higher (ECS, SBM) or practically unchanged (LCS, MBM) when bags were recovered from 
Table 3. Least squares means for dry matter $(D M)$, nitrogen and neutral-detergent fibre $(N D F)$ disappearance $(\mathrm{g} / \mathrm{kg})$ from intact and rumen-undegradable feeds from mobile bags as influenced by cloth type $(2 / 10(S)$ v. $33 / 41(L) \% / \mu m)$ and site of recovery (ileum $(I) \mathrm{v}$. faeces $(F))$ during passage through the intestine of cattle*

\begin{tabular}{|c|c|c|c|c|c|c|c|c|c|c|c|c|}
\hline \multirow{3}{*}{$\begin{array}{l}\text { Feed nutrient... } \\
\text { Cloth type... } \\
\text { Site of recovery ... }\end{array}$} & \multicolumn{4}{|c|}{ DM } & \multicolumn{4}{|c|}{$\mathbf{N}$} & \multicolumn{4}{|c|}{$\mathrm{NDF}$} \\
\hline & \multicolumn{2}{|c|}{$S$} & \multicolumn{2}{|c|}{ L } & \multicolumn{2}{|c|}{ S } & \multicolumn{2}{|c|}{$\mathbf{L}$} & \multicolumn{2}{|c|}{$\mathrm{s}$} & \multicolumn{2}{|c|}{$\mathrm{L}$} \\
\hline & I & $\mathbf{F}$ & I & $\mathbf{F}$ & I & $F$ & I & $\mathrm{F}$ & 1 & $\mathbf{F}$ & I & $F$ \\
\hline \multicolumn{13}{|l|}{ Intact feed } \\
\hline Grass silage, early cut & 443 & 493 & 518 & 546 & 822 & 859 & 891 & 900 & 64 & 128 & 139 & 186 \\
\hline Grass silage, late cut & 387 & 403 & 447 & 490 & 811 & 799 & 868 & 881 & 55 & 96 & 114 & 176 \\
\hline Rapeseed meal, untreated & 593 & 663 & 646 & 706 & 809 & 867 & 857 & 883 & 131 & 220 & 167 & 274 \\
\hline Rapeseed meal, treated & 579 & 646 & 637 & 709 & 795 & 850 & 840 & 885 & 147 & 231 & 185 & 303 \\
\hline Soya-bean meal & 754 & 820 & 793 & 868 & 889 & 903 & 932 & 960 & 174 & 328 & 215 & 389 \\
\hline Meat-and-bone meal & 617 & 595 & 654 & 670 & 798 & 806 & 828 & 853 & & & & \\
\hline \multicolumn{13}{|l|}{ Rumen-undegraded feed } \\
\hline Grass silage, early cut & 54 & 86 & 104 & 148 & 293 & 288 & 446 & 439 & 40 & 77 & 66 & 117 \\
\hline Grass silage, late cut & 46 & 55 & 99 & 110 & 329 & 248 & 459 & 414 & 32 & 54 & 65 & 87 \\
\hline Rapeseed meal, untreated & 332 & 358 & 385 & 415 & 585 & 619 & 647 & 672 & 121 & 146 & 156 & 186 \\
\hline Rapeseed meal, treated & 388 & 429 & 445 & 487 & 660 & 711 & 731 & 760 & 89 & 140 & 129 & 181 \\
\hline Soya-bean meal & 654 & 753 & 727 & 799 & 825 & 913 & 912 & 955 & 212 & 287 & 234 & 334 \\
\hline Meat-and-bone meal & 320 & 312 & 355 & 353 & 519 & 554 & 582 & 588 & & & & \\
\hline
\end{tabular}

* For details of procedures, see pp. 492-494.

faeces than from the ileum (Table 4). In contrast to intact feeds, $\mathrm{N}$ disappearance from RUD LCS was clearly lower and that from RUD SBM clearly higher, while the other feeds tended to be unchanged or slightly higher (TRSM), when bags were recovered from faeces instead of from the ileum (Table 4).

As regards the possibility of influencing large-intestinal digestion values by appropriate cloth type, no such effect was found $\left(F_{1,87}=0.09, P=0.76\right.$ for site of recovery $x$ cloth type interaction). However, average digestion values obtained with $\mathrm{S}$ bags were clearly lower than those obtained with L bags $(834$ v. $882 \mathrm{~g} / \mathrm{kg}, 95 \%$ CI 39,56 for $\mathrm{L}-\mathrm{S}$ difference). Moreover, with RUD feeds the $\mathrm{L}-\mathrm{S}$ difference was dependent on feed $\left(F_{5,79}=8 \cdot 22, P<\right.$ 0.001 for cloth type $\times$ feed interaction), being nearly threefold higher for grass silages than for concentrates. For grass silages the difference was $150 \mathrm{~g} / \mathrm{kg}(95 \% \mathrm{CI} 126,173)$ and for concentrates $57 \mathrm{~g} / \mathrm{kg}(95 \% \mathrm{CI} \mathrm{41,74)}$.

The effect on $\mathrm{N}$ disappearance of site of recovery was not associated with diet $\left(F_{2,87}=\right.$ $0.27, P=0.76$ for site of recovery $\times$ diet interaction). The slight effect of diet per se on $\mathrm{N}$ digestion values $\left(F_{2,2}=5.97, P=0.14\right.$ for diet) was due to effect of feeding level (A40v. $\mathrm{A} 80$ ) rather than due to diet type (A80 v. B80). The difference between the means for A40

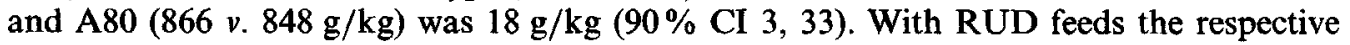
difference between means $(610$ v. $571 \mathrm{~g} / \mathrm{kg})$ was $38 \mathrm{~g} / \mathrm{kg}(90 \% \mathrm{CI}-1,77)$. However, analysis of each of the feeds separately revealed that the RUD LCS was an exceptional feed with regard to response to diet effect. With this particular feed the difference in $\mathbf{N}$ disappearance between FB and IB was negative as shown in Table 4, but this difference was clearly increased due to altering diet type, being much higher on diet $\mathrm{B} 80(-143 \mathrm{~g} / \mathrm{kg}, 95 \%$ $\mathrm{CI}-60,-226)$ than on diet A80 $(-17 \mathrm{~g} / \mathrm{kg}, 95 \% \mathrm{CI}-87,53)$.

Comparison of digestion values of intact feeds revealed no substantial between-feed differences whether measured from IB or from FB (for means see Table 4). In contrast to 
Table 4. Least squares means for dry matter, nitrogen and neutral-detergent fibre disappearance $(\mathrm{g} / \mathrm{kg})$ from intact and rumen-undegradable $(R U D)$ feeds in mobile bags as influenced by feed and site of recovery (faeces $(F)$ v. ileum $(I))$ in cattle*

\begin{tabular}{|c|c|c|c|c|c|c|}
\hline Feed ... & $\mathrm{ECS}$ & LCS & RSM & TRSM & SBM & MBM \\
\hline \multicolumn{7}{|l|}{ Dry matter } \\
\hline $\mathrm{F}$ & 519 & 447 & 685 & 678 & 844 & 633 \\
\hline I & 481 & 417 & 620 & 608 & 773 & 635 \\
\hline$F-I$ & 39 & 30 & 65 & 69 & 70 & -3 \\
\hline $95 \%$ CI for $\mathrm{F}-\mathrm{I}$ & 19,58 & 11,49 & 46,84 & 50,87 & 51,89 & $-22,16$ \\
\hline \multicolumn{7}{|l|}{ RUD feeds } \\
\hline $\mathrm{F}$ & 117 & 83 & 387 & 458 & 776 & 332 \\
\hline I & 79 & 73 & 358 & 416 & 690 & 337 \\
\hline $\mathbf{F}-\mathbf{I}$ & 38 & 10 & 29 & 42 & 86 & -5 \\
\hline $95 \% \mathrm{CI}$ for $\mathrm{F}-\mathrm{I}$ & 16,59 & $-10,31$ & 8,49 & 21,62 & 65,107 & $-26,16$ \\
\hline \multirow{2}{*}{\multicolumn{7}{|c|}{$\begin{array}{l}\text { Nitrogen } \\
\text { Intact feeds }\end{array}$}} \\
\hline & & & & & & \\
\hline $\mathbf{F}$ & 879 & 840 & 875 & 867 & 931 & 829 \\
\hline I & 857 & 839 & 833 & 817 & 910 & 813 \\
\hline$F-I$ & 22 & 1 & 42 & 50 & 21 & 16 \\
\hline $95 \% \mathrm{CI}$ for $\mathrm{F}-\mathrm{I}$ & 2,43 & $-20,21$ & 22,62 & 29,70 & 1,41 & $-4,36$ \\
\hline \multicolumn{7}{|l|}{ RUD feeds } \\
\hline $\mathrm{F}$ & 364 & 331 & 645 & 735 & 934 & 571 \\
\hline I & 370 & 394 & 616 & 695 & 869 & 550 \\
\hline $\mathrm{F}-\mathrm{I}$ & -6 & -63 & 30 & 40 & 65 & 21 \\
\hline $95 \% \mathrm{CI}$ for $\mathrm{F}-\mathrm{I}$ & $-42,29$ & $-97,-29$ & $-4,64$ & 6,74 & 31,100 & $-14,55$ \\
\hline \multicolumn{7}{|l|}{ Neutral-detergent fibre } \\
\hline \multicolumn{7}{|l|}{ Intact feeds } \\
\hline $\mathrm{F}$ & 157 & 136 & 247 & 267 & 359 & \\
\hline I & 102 & 84 & 149 & 166 & 195 & \\
\hline $\mathrm{F}-\mathrm{I}$ & 56 & 52 & 98 & 101 & 164 & \\
\hline $95 \% \mathrm{CI}$ for $\mathrm{F}-\mathrm{I}$ & 37,74 & 34,70 & 80,116 & 83,119 & 145,182 & \\
\hline \multicolumn{7}{|l|}{ RUD feeds } \\
\hline $\mathbf{F}$ & 97 & 70 & 166 & 160 & 223 & \\
\hline I & 53 & 48 & 138 & 109 & 310 & \\
\hline $\mathrm{F}-\mathrm{I}$ & 44 & 22 & 28 & 51 & 87 & \\
\hline $95 \% \mathrm{CI}$ for $\mathrm{F}-\mathrm{I}$ & 26,62 & 5,39 & 10,45 & 34,68 & 69,105 & \\
\hline
\end{tabular}

ECS, early-cut silage; LCS, late-cut silage; RSM, rapeseed meal; TRSM, heat-moisture treated rapeseed meal; SBM, soya-bean meal; MBM, meat-and-bone meal.

* For details of procedures, see pp. 492-494.

intact feeds, more obvious differences between the individual RUD feeds were detected (Table 4). In particular the difference between the concentrates and grass silages $(301 \mathrm{~g} / \mathrm{kg}$ (SED 15) for IB and $374 \mathrm{~g} / \mathrm{kg}$ (SED 13) for FB) was obvious. Irrespective of the site of recovery, the digestibility of TRSM was higher than that of RSM, and the digestibility of SBM was higher than that of MBM, whereas no significant differences were found between RUD silages.

\section{Fibre disappearance from mobile bags}

The effect of site of recovery on NDF disappearance from bags was dependent on feed type $\left(F_{4,71}=24.3, P<0.001\right.$ for site of recovery $\times$ feed interaction $)$. The NDF disappearance was higher for all feeds when bags were recovered from faeces instead of from the ileum 


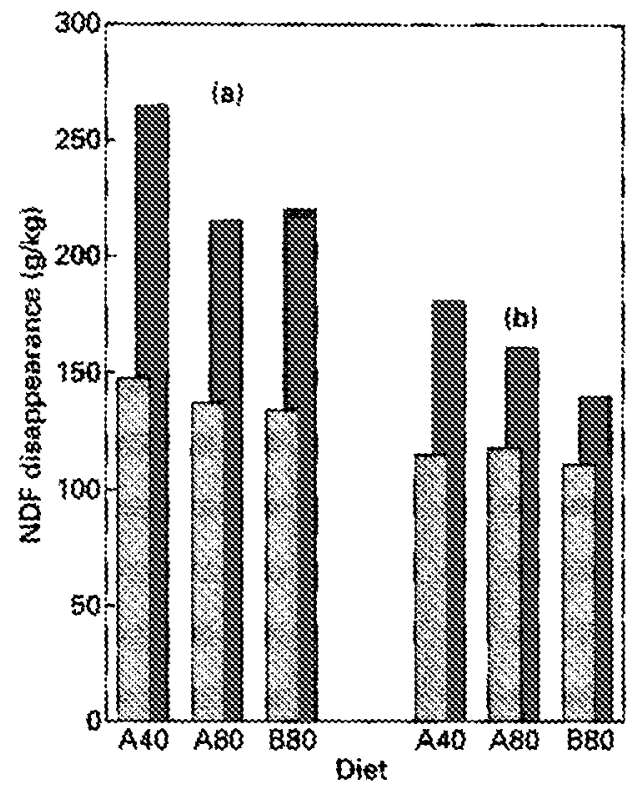

Fig. 1. The effect of site of recovery (ileum (圈), faeces (임)) and diet on disappearance of neutral-detergent fibre (NDF) of $(a)$ intact and $(b)$ rumen-undegraded feeds from mobile bags during passage through the intestine of cattle. For diets, see Table 5.

(Table 4). The effect of site of recovery also tended to be associated with the cloth type $\left(F_{1,71}\right.$ $=3 \cdot 80, P=0.06$ for site of recovery $\times$ cloth type interaction). The difference between faeces and ileum was $86 \mathrm{~g} / \mathrm{kg}(95 \%$ CI 75,98$)$ when measured from S bags and $102 \mathrm{~g} / \mathrm{kg}(95 \%$ CI 90, 113) when measured from L bags. However, no such effect was detected with RUD feeds $\left(F_{1,66}=1.43, P=0.24\right.$ for site of recovery $\times$ cloth type interaction $)$.

The effect of site of recovery was also dependent on diet $\left(F_{2,71}=8.37, P<0.001\right.$ for site of recovery $\times$ diet). The measurements made from IB were nearly equal for different diets (Fig. 1). However, the FB - IB difference on diet A40 was $40 \mathrm{~g} / \mathrm{kg}(95 \%$ CI 20, 60) higher than that on diet $\mathrm{A} 80$, while no corresponding difference due to diet type was found. With RUD feeds the respective difference was slightly lower, $24 \mathrm{~g} / \mathrm{kg}(95 \% \mathrm{CI} 4,43)$.

\section{Retention time of mobile bags in the intestine}

The retention time (RT) of mobile bags in the intestine was influenced by site of recovery $\left(F_{1,85}=333.3, P<0.001\right)$ and diet $\left(F_{2,2}=41.8, P=0.02\right)$. The RT was doubled when bags were recovered from faeces instead of from the ileum and it was longer for bags collected on a low than for those collected on a high level of feeding (Table 5). However, the shortest RT for IB and FB, recorded on diets fed at a high level of feeding, were 5 and $12 \mathrm{~h}$ respectively.

\section{Expt 2}

Organic matter (OM) digestibilities of experimental diets are given in Table 6. Apparent digestibility of OM decreased with increasing feeding level $\left(F_{1,2}=97 \cdot 0, P=0.01\right)$ and as the type of diet changed $\left(F_{1.2}=391.9, P<0.005\right.$; Table 6$)$. The site of $O M$ digestion was shifted from the forestomachs towards the post-ruminal tract when the diet changed from A80 to $\mathrm{B} 80\left(F_{1,2}=15 \cdot 3, P=0.06\right)$. The faecal $\mathrm{N}$ content increased due to diet type $\left(F_{1,2}=\right.$ 68.7, $P=0.01$ ), being 26, 26 and 31 (SEM 0.53) $\mathrm{g} / \mathrm{kg}$ DM on diets A40, A80 and B80 
Table 5. Mean retention time $(h)$ of mobile bags containing intact and rumen-undegradable $(R U D)$ feeds during passage through the intestine of cattle as influenced by the site of recovery (faeces $(F)$ v. ileum $(I)$ ) and diet ${ }^{*} \dagger$

\begin{tabular}{lrrlrr}
\hline \hline Site of recovery & Intact & RUD & Diet & Intact & RUD \\
\hline F & 25 & 24 & A40 & 23 & 21 \\
I & 12 & 11 & A80 & 15 & 16 \\
F-I & 13 & 13 & B80 & 17 & 16 \\
$95 \%$ CI & 11,14 & 12,15 & A40-A80 & 8 & 5 \\
& & & $95 \%$ CI & 4,12 & 0,10 \\
\hline
\end{tabular}

* Diets A40 and A80, grass silage-barley (70:30 on a dry matter (DM) basis) at 40 and $80 \mathrm{~g} \mathrm{DM} / \mathrm{kg} \mathrm{W}^{0.75}$; diet B80, grass silage-dried and pelleted grass-barley-sucrose $\left(20: 35: 30: 15\right.$ on a DM basis) at $80 \mathrm{~g} \mathrm{DM} / \mathrm{kg} \mathrm{W}^{0.75}$. Sucrose was given as a continuous intrarumen infusion.

$\dagger$ For details of procedures, see pp. 492-494.

Table 6. The effects of feeding level and type of diet* on mean retention time $(M R T)$ of $Y b$ labelled digesta particles in the intestine and organic matter $(O M)$ digestibility in cattle $\dagger$

\begin{tabular}{|c|c|c|c|c|c|}
\hline \multirow[b]{2}{*}{ Diet ... } & \multirow[b]{2}{*}{$\mathbf{A 4 0}$} & \multirow[b]{2}{*}{ A80 } & \multirow[b]{2}{*}{ B80 } & \multicolumn{2}{|c|}{$95 \% \mathrm{CI}$ for differences (df 2 ) } \\
\hline & & & & $\mathbf{A} 40-\mathbf{A} 80$ & $A 80-B 80$ \\
\hline MRT & $17 \cdot 2$ & 12.9 & $14 \cdot 2$ & $1.0,7 \cdot 6$ & $-4 \cdot 5, \overline{2 \cdot 0}$ \\
\hline $\begin{array}{l}\text { OM digestibility } \\
\text { Rumen } \\
\text { Total } \\
\text { Rumen/total }\end{array}$ & $\begin{array}{l}0.649 \\
0.798 \\
0.813\end{array}$ & $\begin{array}{l}0.624 \\
0.773 \\
0.806\end{array}$ & $\begin{array}{l}0.503 \\
0.724 \\
0.696\end{array}$ & $\begin{array}{r}-0.058,0.110 \\
0.014,0.036 \\
-0.114,0.128\end{array}$ & $\begin{array}{r}0.036,0.205 \\
0.039,0.060 \\
-0.011,0.231\end{array}$ \\
\hline
\end{tabular}

* Diets A40 and A80, grass silage-barley (70:30 on a dry matter (DM) basis) at 40 and $80 \mathrm{~g} \mathrm{DM} / \mathrm{kg} \mathrm{W0-75}$; diet B80, grass silage-dried and pelleted grass-barley-sucrose $\left(20: 35: 30: 15\right.$ on a DM basis) at $80 \mathrm{~g} \mathrm{DM} / \mathrm{kg} \mathrm{W}^{0 \cdot 75}$. Sucrose was given as a continuous intrarumen infusion.

$\dagger$ For details of procedures, see pp. $492-494$.

respectively. The MRT of $\mathrm{Yb}$ in the intestine decreased with increasing feeding level $\left(F_{1,2}=\right.$ 32.0, $P<0.03)$, but it was not influenced by diet type $\left(F_{1,2}=2 \cdot 7, P=0 \cdot 24\right.$; Table 6$)$.

\section{DISCUSSION}

Dry matter and nitrogen disappearance

A significant interaction between the effects of site of recovery and feed in Expt 1 indicated that the influence of digestion in the large intestine on intestinal disappearance of DM and $\mathrm{N}$ was dependent on feed type. With the exception of MBM, recovery of bags from faeces usually resulted in a quantitatively small overestimation of small-intestinal digestion of $\mathrm{DM}$ and $\mathrm{N}$ with intact concentrates. The same trend, although not so obvious, was found with RUD feeds (Table 4). Slight overestimation (on average 3.5 percentage units) of smallintestinal $\mathbf{N}$ digestibility of intact concentrates such as linseed meal, barley, wheat and maize, SBM, sunflower-seed meal and pea (Voigt et al. 1985; Jarosz et al. 1991; Todorov \& Girginov, 1991), or of rumen-undegradable feeds such as SBM, RSM and heat-treated SBM (Hvelplund, 1985, 1986), has also been shown from FB. On the other hand, no difference between IB and FB in N digestibility of rumen-undegradable SBM, palm-kernel 
cakes, heat-damaged fish meal (Hvelplund, 1986) or of intact RSM and fish meal (Voigt et al. 1985) could be detected.

Hvelplund (1985) found that $50 \%$ of the protein of RUD SBM leaving the small intestine and $27 \%$ of RUD RSM was digested in the large intestine. In the present study the corresponding figures for SBM and RSM can be calculated to be similar for SBM but lower for the RSM feeds, varying from 7 to $13 \%$ for RSM and TRSM respectively (Table 4). The lower values for RSM may be related to the low content of fibre-bound $\mathrm{N}$ in the yellow-seeded variety, which was used in the present experiment (Table 2). Todorov $\&$ Girginov (1991) using intact samples noticed also that $44 \%$ of $\mathrm{N}$ in SBM and $28 \%$ of $\mathrm{N}$ in sunflower-seed meal remaining in the bags after passing the small intestine was further digested in the large intestine, although it did not affect significantly the total intestinal digestibility due to the small quantity of the remaining feed $\mathrm{N}$. In the present experiment it can be calculated (Table 4) that large-intestinal $\mathbf{N}$ digestion accounted for not more than, at maximum, $7 \%$ of the total intestinal mobile-bag digestion of vegetable concentrates.

The digestibility values of MBM, measured from IB or FB, did not statistically differ from each other in the present experiment. Neither did Voigt et al. (1985) find any differences in corresponding digestibility values of fish meal. This is probably simply due to the fact that, being of animal origin, these feeds do not contain fibre-bound $N$. De Boer et al. (1987), however, found rumen-incubation to be an important prerequisite for intestinal disappearance of MBM, since the $\mathrm{N}$ digestibility of intact $\mathrm{MBM}$ was much lower than that of the corresponding RUD feed in their study. This effect was not obtained in the present study because the intestinal digestibility of RUD MBM was, as for other feeds, lower than that of intact feed.

In contrast to the slight overestimation with most vegetable concentrates, FB digestibilities of DM and N of grass silages were unchanged compared with their respective IB digestibilities. However, with RUD LCS, which was highest in fibre, FB digestibility of $\mathrm{N}$ was clearly lower than that of IB resulting in an average underestimation of $16 \%$ of IB. In accordance with the present results, FB digestibility of intact roughages such as lucerne (Medicago sativa; Voigt et al. 1985; Todorov \& Girginov, 1991), red clover (Trifolium pratense), grass hay (Voigt et al. 1985) and grass pellets (Hvelplund, 1986) remained practically unchanged compared with IB values, whereas clearly lower FB values were obtained with barley straw (Jarosz et al. 1991). Varvikko \& Vanhatalo (1990) reported a noticeable proportion of non-feed $\mathrm{N}$ in the feed residues within $\mathrm{FB}$, especially with fibrous feeds with low N. Recently, Jarosz et al. (1991) found underestimation of $\mathbf{N}$ disappearance for most of the roughages under test due to microbial attachment not only in the large intestine but also in the small intestine. The large-intestinal microflora, however, were regarded as a major source of error for this discrepancy. Here, the difference in response to large-intestinal digestion between concentrates and roughages is probably also associated with non-feed $\mathrm{N}$ in the feed residues due to microbial fermentation in the large intestine. With feeds, such as whole crop pea (Jarosz et al. 1991) and RSM (Vanhatalo \& Varvikko, 1993), microbial contamination within FB was found to be very small, although it increased slightly when pre-incubation in the rumen preceded measurement in the latter study.

The difference in DM and $\mathrm{N}$ disappearance between $\mathrm{L}$ and $\mathrm{S}$ bags corresponds to the results by Varvikko \& Vanhatalo (1990), but it does not appear to be associated with largeintestinal digestion as expected, since it was obvious with bags from either collection site. Partly, the difference between $\mathrm{L}$ and $\mathrm{S}$ bags may be associated with particle loss from the bags. Voigt et al. (1985) compared bag cloths with pore sizes of $32-70 \mu \mathrm{m}$, which were larger than those used in the present experiment $(10-41 \mu \mathrm{m})$, but could not find any relationship between pore size and digestibility or losses by washing. Hvelplund (1985) on the other hand decided to use cloth with a smaller pore size $(9 v .22 \mu \mathrm{m})$ in order to avoid 
losses of feed particles from bags. Todorov \& Girginov (1991) found that protein disappearance from bags increased with increasing pore size $(10-80 \mu \mathrm{m})$ and that the influence of pore size was more pronounced with maize and lucerne meal than with SBM or sunflower-seed meal. Regarding RUD feeds, this was also true in the present experiment, as the difference between $\mathbf{L}$ and $\mathbf{S}$ bags was more pronounced with grass silages compared with concentrates. Provided that the particle loss can be estimated as a difference between wash-related loss and solubility of the feed (Weisbjerg et al. 1990; Lopez et al. 1994), it can be calculated (Table 2) that except for grass silages, the particle losses of DM and N were higher from $\mathbf{L}$ than from $\mathbf{S}$ bags. However, correction of the disappearance values of concentrates due to particle loss (Weisbjerg et al. 1990) resulted in a reduction of not more than 4.8 and 1.9 percentage units in disappearance values of DM and $\mathrm{N}$ when averaged over feeds and cloth types (results not shown). Moreover, the particle loss explained the difference in disappearance values between $L$ and $S$ bags, only on average 2.0 percentage units with DM and 0.9 percentage units with $\mathrm{N}$. With grass silages, especially when using $S$ bags, the difference between washout values and solubilities of DM and $N$ was negative, which indicates that not all of the soluble material in the bag disappears during washing. This suggests that concentrates and forages may have a different response to washing of bags and that the $S$ cloth used in the present experiment may not be appropriate to use with forages. Recent findings by Van Straalen et al. (1993), who observed different effects of two washing procedures (less intensive $v$. intensive) on disappearance values of concentrate feedstuffs and forages, may support this suggestion.

With the exception of RUD LCS, the effects of diet and recovery site were not associated with each other and thus it can be concluded that variation in the large-intestinal fermentation due to diet does not generally confuse determination of intestinal mobile-bag digestion values of DM and $\mathrm{N}$. Due to the diet effect per se, mobile-bag digestion values of intact feeds tended to decrease slightly with increasing feeding level. However, they were not affected by the diet type, although measurements of in vivo digestibility of diets showed that digestion was shifted from the forestomachs to the post-ruminal tract on diet B80 compared with diet A80 (Table 6). The faecal $\mathrm{N}$ excretion, higher on diet B80 than on diet A80, can also be considered as an indication of greater extent of fermentation in the large intestine (Ørskov et al. 1971). In contrast to other feeds, the $\mathbf{N}$ disappearance value of RUD LCS was affected by the increased large-intestinal fermentation, resulting in a clearly reduced digestion value as measured from FB on diet B80. Obviously increased microbial activity on diet $\mathrm{B} 80$ responded to the surface of feed residue, which was higher in fibre and larger in volume compared with the content of other feed residues entering the large intestine.

The small-intestinal digestibility of undegraded dietary protein of roughages, measured from IB, was clearly lower than that of concentrates in the present study. This is in accordance with the earlier findings, which are based, however, on the FB measurements (Van Straalen \& Tamminga, 1990; Frydrych, 1992), that may have suffered from the nonfeed $\mathrm{N}$ effect.

\section{NDF disappearance and retention time of bags}

The NDF disappearance of feeds was clearly higher from FB than from IB, emphasizing the role of the large intestine in post-ruminal fibre digestion. However, some disappearance of fibre occurred also in the small intestine even from $S$ bags, although $S$ cloth tended to limit disappearance of fibre from intact feeds in the large intestine more than $\mathrm{L}$ bags. The disappearance of NDF from bags in the small intestine may be simply particle loss, otherwise it indicates microbial activity in the small intestine (Ulyatt et al. 1975; Jarosz et al. 1991; Kijora et al. 1992). However, in a previous study (Vanhatalo et al. 1992), a 
noticeable disappearance of lignin was obtained from grass in mobile bags within the intestine, which was interpreted to represent a dissolved rather than an absorbed proportion of the feed lignin. In the present study the NDF disappearance from bags in the small intestine may represent at least partially a disappearance of fibre-bound $\mathbf{N}$.

The absence of a diet effect with IB (Fig. 1) suggests that increased fibre disappearance of feeds in the intestine at a low level of feeding was associated merely with large-intestinal digestion. This was consistent with the results concerning the RT of bags (Table 5) and MRT of Yb-labelled digesta particles within the intestine (Table 6), which were longer on a low than on a high level of feeding. The MRT of Yb-labelled digesta particles was similarly affected by feeding level as $\mathrm{Cr}$ - and $\mathrm{Yb}$-labelled digesta particles in a recent study by Huhtanen \& Kukkonen (1995). The shorter MRT of Yb-labelled digesta particles in the intestine compared with the RT of mobile bags may be partly due to incomplete recording of bags. On the other hand, the shorter MRT of Yb obtained in the present study may support the conclusion (Hvelplund, 1985) that the bags travel through the small intestine at a slower rate than particulate matter. Although the average RT of the bags collected from the ileum and faeces (Table 5) tended to be longer than in studies carried out with dairy cows (Hvelplund, 1985; Voigt et al. 1985), the shortest RT recorded on high levels of feeding in the present study were equal to the respective observations found earlier. However, the length of retention time of bags within the intestine seems to affect only fibre digestion of feeds in the large intestine, as the change in feeding level did not practically influence disappearance of DM and $\mathrm{N}$ from bags in the present study. In other studies, no relationship between passage time of bags and DM disappearance (Van Straalen et al. 1993) or N disappearance (Hvelplund, 1985; Voigt et al. 1985) has been found, though a time-related correlation with DM disappearance was observed (Voigt et al. 1985).

In summary, the present results show that collecting bags from faeces instead of from the ileum caused a quantitatively small overestimation of small-intestinal $\mathbf{N}$ digestion of vegetable concentrates. On the other hand, a clear underestimation of small-intestinal $\mathrm{N}$ digestion of rumen-undegradable feed high in fibre, obviously because of non-feed $\mathrm{N}$, was caused due to faecal collection of bags. The hypothesis to isolate the large-intestinal $\mathbf{N}$ digestion by manipulating the bag cloth used was not supported by the present results. The effect of diet on intestinal $\mathrm{N}$ digestion values of feeds was usually negligible. It is concluded that the site of collection of bags does not practically affect small-intestinal digestion values of feed $\mathrm{N}$, unless the feed is rich in fibre.

The authors thank Dr Tuomo Varvikko for critically reading the manuscript. The technical assistance of Ms Aino Matilainen and Ms Seija Virtanen in this study is gratefully acknowledged. The authors are also grateful to Mr Martti Tala for surgery of the experimental animals.

\section{REFERENCES}

Agricultural Research Council (1980). The Nutrient Requirements of Ruminant Livestock. Slough: Commonwealth Agricultural Bureaux.

Agricultural Research Council (1984). The Nutrient Requirements of Ruminant Livestock Supplement no. 1. Slough: Commonwealth Agricultural Bureaux.

Aronen, I., Toivonen, V., Ketoja, E. \& Öfversten, J. (1992). Beef production as influenced by stage of maturity of grass for silage and level and type of supplementary concentrates. Agricultural Science in Finland 1, 441-460.

Blaxter, K. L., Graham, N. McC. \& Wainman, F. W. (1956). Some observations on the digestibility of food by sheep and on related problems. British Journal of Nutrition 10, 69-91.

De Boer, G., Murphy, J. J. \& Kennelly, J. J. (1987). Mobile nylon bag for estimating intestinal availability of rumen undegradable protein. Journal of Dairy Science 70, 977-982.

Frydrych, Z. (1992). Intestinal digestibility of rumen undegraded protein of various feeds as estimated by the mobile bag technique. Animal Feed Science and Technology 37, 161-172. 
Hoover, W. H. (1978). Digestion and absorption in the hindgut of ruminants. Journal of Animal Science 46, 1789-1798.

Huhtanen, P. \& Khalili, H. (1991). Sucrose supplements in cattle given grass silage-based diet. 3 . Rumen pool size and digestion kinetics. Animal Feed Science and Technology 33, $275-287$.

Huhtanen, P. \& Khalili, H. (1992). The effect of sucrose supplements on particle-associated carboxymethylcellulase $(E C$ 3.2.1.4) and xylanase (EC 3.2.1.8) activities in cattle given grass-silage-based diet. British Journal of Nutrition 67, 245-255.

Huhtanen, P. \& Kukkonen, U. (1995). Comparison of methods, markers, sampling sites and models for estimating digesta passage kinetics in cattle fed at two levels of intake. Animal Feed Science and Technology (In the Press).

Hvelplund, T. (1985). Digestibility of rumen microbial protein and undegraded dietary protein estimated in the small intestine of sheep and by in sacco procedure. Acta Agriculturae Scandinavica 25, Suppl., $132-144$.

Hvelplund, T. (1986). Estimation of nitrogen digestibility in undegraded dietary protein by the in sacco procedure. In Nuclear and Related Techniques in Animal Production and Health, pp. 641-643. Vienna: IAEA.

Hvelplund, T. \& Madsen, J. (1990). A study of the quantitative nitrogen metabolism in the gastro-intestinal tract, and the resultant new protein evaluation system for ruminants. The AAT-PBV system. Dissertation, Institute of Animal Science, The Royal Veterinary and Agricultural University, Copenhagen. Odense: AiO Tryk as.

Hvelplund, T., Weisbjerg, M. \& Andersen, L. (1992). Estimation of the true digestibility of rumen undegraded dietary protein in the small intestine of ruminants by the mobile bag technique. Acta Agriculturae Scandinavica, Section A, Animal Science 42, 3439.

Jarosz, L., Weisbjerg, M. R., Hvelplund, T. \& Borg Jensen, B. (1991). Digestibility of nitrogen and ${ }^{15} \mathrm{~N}$ from different roughages in the lower gut of cows estimated with the mobile nylon bag procedure. In Protein Metabolism and Nutrition. Proceedings of the 6th International Symposium on Protein Metabolism and Nutrition. EAAP Publication no. 59, vol. 2, pp. 113-115 [B. O. Eggum, S. Boisen, C. Børsting, A. Danfær and T. Hvelplund, editors]. Tjele: National Institute of Animal Science, Research Centre Foulum.

Kijora, C., Bergner, H., Szakacz, J., Bartelt, J. \& Götz, K.-P. (1992). Utilization of ${ }^{15} \mathrm{~N}$-urea infusion in the small intestine. Journal of Animal Physiology and Animal Nutrition 67, 238-249.

Kirkpatrick, B. K. \& Kennelly, J. J. (1985). The mobile bag technique as a predictor of the nutritive value of feedstuffs for dairy cattle. Agriculture and Forestry Bulletin, Special Issue. 64th Annual Feeders' Day Report, pp. 12-13. Alberta: University of Alberta.

Lopez, S., France, J. \& Dhanoa, M.S. (1994). A correction for particulate matter loss when applying the polyester-bag method. British Journal of Nutrition 71, 135-137.

Meyer, J. H. F. \& Mackie, R. I. (1986). Microbiological evaluation of the intraruminal in sacculus digestion technique. Applied and Environmental Microbiology 51, 622629.

Neter, J., Wasserman, W. \& Kutner, M. H. (1990). Applied Linear Statistical Models, 3rd ed. Boston: Irwin.

Ørskov, E. R., Fraser, C. \& McDonald, I. (1971). Digestion of concentrates in sheep. 2. The effect of urea or fishmeal supplementation of barley diets on the apparent digestion of protein, fat, starch and ash in the rumen, the small intestine and the large intestine, and calculation of volatile fatty acid production. British Journal of Nutrition 25, 225-252.

Rae, R. C. \& Smithard, R. R. (1985). Estimation of true nitrogen digestibility in cattle by modified nylon bag technique. Proceedings of the Nutrition Society 44, 116A.

Robertson, J. B. \& Van Soest, P. J. (1981). The detergent system of analysis and its application to human foods. In The Analysis of Dietary Fibre in Foods, pp. 123-158 [W. P. T. James \& O. Theander, editors]. New York: Marcel Dekker.

Rooke, J. A. (1985). The nutritive values of feed protein residues resistant to degradation by rumen microorganisms. Journal of the Science of Food and Agriculture 36, 629-637.

SAS Institute Inc. (1990). SAS Procedures Guide, Version 6, 3rd ed. Cary, NC: SAS Institute Inc.

SAS Institute Inc. (1992). SAS Technical Report P-229, SAS/STAT Software: Changes and Enhancements, Release 6.07. Cary, NC: SAS Institute Inc.

Sauer, W. C., Jorgensen, H. \& Berzins, R. (1983). A modified nylon bag technique for determining apparent digestibilities of protein in feedstuffs for pigs. Canadian Journal of Animal Science 63, 233-237.

Todorov, N. A. \& Girginov, D. G. (1991). Comparison of the infusion method, mobile bag technique and in vitro method for determination of the protein digestibility in small intestine of cattle. In Protein Metabolism and Nutrition. Proceedings of the 6th International Symposium on Protein Metabolism and Nutrition. EAAP publication no. 59, vol. 2, pp. 80-82 [B. O. Eggum, S. Boisen, C. Børsting, A. Danfær and T. Hvelplund, editors]. Tjele: National Institute of Animal Science, Research Centre Foulum.

Tukey, J. W. (1977). Exploratory Data Analysis. Reading, MA: Addison-Wesley.

Ulyatt, M. J., Dellow, O. W., Reid, C. S. \& Bauchop, T. (1975). Structure and function of the large intestine of ruminants. In Digestion and Metabolism in Ruminants, pp. 119-133 [I. W. McDonald and A. C. I. Warner, editors]. Armidale: University of New England Publishing Unit.

Van Straalen, W. M., Dooper, F. M. H., Antoniewicz, A. M., Kosmala, I. \& Van Vuuren, A. M. (1993). Intestinal digestibility in dairy cows of protein from grass and clover measured with mobile nylon bag and other methods. Journal of Dairy Science 76, 2970-2981.

Van Straalen, W. M. \& Tamminga, S. (1990). Protein degradation of ruminant diets. In Feedstuff Evaluation, pp. 55-72 [J. Wiseman \& D. J. A. Cole, editors]. London: Butterworths. 
Vanhatalo, A., Dakowski, P. \& Huhtanen, P. (1992). Ruminal and intestinal degradation of grass cut at different stages of growth. Proceedings of the 14th General Meeting of the European Grassland Federation, pp. 412-415. Lahti: European Grassland Federation.

Vanhatalo, A. \& Varvikko, T. (1993). Intestinal nitrogen digestibility of ${ }^{15} \mathrm{~N}$-labelled rapeseed meal measured by mobile-bag method. In Proceedings of the Society of Nutrition Physiology, vol. 1, p. 60, [H.-H. Freese, editor] Frankfurt am Main: DLG-Verlag.

Vanhatalo, A., Varvikko, T. \& Aronen, I. (1992). The effect of type of additive on rumen fermentation and digestion of grass silage in cattle. Agricultural Science in Finland 1, 163-175.

Varga, G. A. \& Prigge, E. C. (1982). Influence of forage species and level of intake on ruminal turnover rates. Journal of Animal Science 55, 1498-1504.

Varvikko, T. \& Vanhatalo, A. (1990). The effect of differing types of cloth and of contamination by non-feed nitrogen on intestinal digestion estimates using porous synthetic-fibre bags in a cow. British Journal of Nutrition 63, 221-229.

Voigt, J. \& Piatkowski, B. (1983). Methode zur Untersuchung der Qualität des Futterproteins beim Wiederkäuer. (A method to evaluate quality of dietary protein in ruminants). Archiv für Tierernährung 33, 531.

Voigt, J., Piatkowski, B., Engelmann, H. \& Rudolph, E. (1985). Measurement of the postruminal digestibility of crude protein by the bag technique in cows. Archiv für Tierernährung 35, 555-562.

Weisbjerg, M. R., Bhargava, P. K., Hvelplund, T. \& Madsen, J. (1990). Use of Degradation Curves in Feed Evaluation. Report from the National Institute of Animal Science, no. 679. Frederiksberg: Boktrykeri as. 